\title{
Metaphors in Indonesian Nature Tourism Discourse: Disclosing Cognition about Nature
}

\author{
Ekaning Krisnawati*, Heriyanto Darsono, Rosaria Mita Amalia, Eva Tuckyta \\ Sari Sujatna and Kasno Pamungkas \\ Department of Linguistics, Faculty of Cultural Sciences, Universitas Padjadjaran, Sumedang 45363, Indonesia
}

\begin{abstract}
Research about nature as an object of tourist gaze has been carried out to cover the relationship between nature, language, and tourists. Due to the increased tourists' desire to have full commitment to enjoying nature, communicating what nature offers and revealing people's behavior and concept about nature is, therefore, important. The concept of nature leading to ways to treat nature can be expressed in language, little, however, has been done to disclose how language shapes and conceptualizes nature, in particular in tourism discourse. This research aims at disclosing the concept of nature, which also reveals humans' cognition about nature, constructed through metaphors in tourism discourse. Employing the theory of Conceptual Metaphor and the procedure of Metaphor Identification Procedure Vrije Universitet (MIPVU), this study analyzes metaphors in an online tourism magazine that describes Indonesian nature. In this study, the concepts of nature as heaven, a person, an object to be identified, and an entity are disclosed. The concept of nature as a person is the most frequently constructed notion. Comprehending this, as a result, can suggest ways how humans treat nature.
\end{abstract}

Keywords: Cognition, discourse, metaphor, nature, tourism

ARTICLE INFO

Article history:

Received: 18 August 2021

Accepted: 24 September 2021

Published: 08 December 2021

DOI: https://doi.org/10.47836/pjssh.29.4.21

$\overline{\text { E-mail addresses: }}$

ekaning@unpad.ac.id (Ekaning Krisnawati) heriyanto@unpad.ac.id (Heriyanto Darsono)

rosaria.mita.amalia@unpad.ac.id (Rosaria Mita Amalia)

eva.tuckyta@unpad.ac.id (Eva Tuckyta Sari Sujatna)

kasno.pamungkas@unpad.ac.id (Kasno Pamungkas)

* Corresponding author

\section{INTRODUCTION}

Nature is one of the objects of the tourist gaze, and tourism, as a result, has been produced, organized, and maintained around views of natural landscapes and townscapes. Only recently has viewing life been elevated to mean experiencing it for the tourists or visitors themselves (Franklin, 2003). The relationship between nature and visitors 
has transformed into a new paradigm. In a zoo, for example, visitors now view animals not as a pure display of performance but as an exhibition of their interest in the wellbeing of the animals, such as how animals are bred or put in captivity due to potential extinction. Similar activities are carried out in nature; visitors enjoy nature in a new way; they desire to experience nature in full commitment, such as rock and mountain climbing, rafting, canoeing, diving, etc. Some reasons for this transformation are frictional problems such as queues, traffic congestion, and crime. Due to globalized information, new, high-risk muscular leisure activities become the purpose of traveling, and environmentalism contributes to the changing of nature tourism (Franklin, 2003). Although the world (cities, nature, history, cultural events) is commodified as tourist products (Judd, 1999; Meethan, 2001), Thrift (2001) suggests that contemporary tourists search for more embodied tourism of nature.

One way to promote nature tourism is through promotion in brochures, leaflets, tourism websites, newspapers, and magazines. An extensive body of research has investigated the significance of visual images on tourism advertisements and discourse, indicating that visual representation of images plays an important role in tourism (Govers et al., 2007; Jaworski \& Pritchard, 2005; Pink, 2007; Scarles, 2010). However, according to Dann (1996), the language of tourism is crucial as it intends to persuade people to become tourists. Some research reveals that visual images and verbal texts impact tourist behavior, particularly purchase intentions (Bigné et al., 2001; Chen \& Tsai, 2007).

One notion in verbal communication is the metaphor. Many writers have discussed different aspects of metaphors in tourism and leisure studies, event management, and the hospitality industry (Elliot et al., 2013; Laing \& Crouch, 2009; Larson, 2009; Morgan \& Pritchard, 2005; Urry, 2000, 2002; Urry \& Larsen, 2011). However, with the wide array of tourism research, little attention has been paid to metaphor in tourism discourse to disclose how people view and conceptualize nature. Therefore, a study on metaphor in tourism discourse is crucial, and this has led the authors to research metaphor in describing nature to reveal the cognition of human beings. This study attempts to disclose humans' cognition about nature as expressed in the Indonesian adventure theme of tourism discourse from cognitive linguistic approach.

\section{LITERATURE REVIEW}

\section{Metaphor and Discourse}

The traditional view on metaphors has proposed an emphasis on creating poetic imagination and rhetoric. Metaphors have always been closely associated with literature and the arts, indicating the deviance of human thoughts (Goatly, 1997). However, this assumption has been challenged by the cognitive view suggesting that metaphors are prevalent and are conceptualized in human thoughts as they are encountered in daily life. Steen (2007) states that conceptual structures reflected in semantic structures are embodied in our experiences. It means 
that metaphors prevail in our language and thought (Lakoff \& Johnson, 1980; Steen, 2007).

Studies on metaphor from a cognitive view have been motivated by the seminal work of Lakoff and Johnson (1980) on metaphor, producing the Conceptual Theory of Metaphor. According to them, metaphor is encountered in daily life as the following examples illustrate:

(1) "Your claims are indefensible." (Lakoff \& Johnson, 1980, p. 4)

(2) "He attacked every weak point in my argument." (p. 4)

(3) "I've never won an argument with him." (p. 4)

Examples (1-3) explicate how the metaphor ARGUMENT IS WAR is conceptualized. In this sense, the words "defense," "attack," "demolish," and "win" are associated with war, so the conceptual metaphor of arguments as war is constructed. When arguing, one party views the other party as an opponent who can attack the position and, as a result, the party needs to defend its position. It is similar to an argument in which the parties involved use strategies to win.

Language usage on something not referred originally to demonstrate similarity or link comparable things is a metaphor (Knowles \& Moon, 2006; Milstein, 2016). Cruse (2000) states a similar definition mentioning that a metaphor is the use of words to refer to things different from their literal meanings. Goatly claims that a metaphor "occurs when a unit of discourse is used to refer unconventionally to an object, process or concept, or colligates in an unconventional way" (1997, p. 8). He adds that a metaphor is comprehended based on similarity, matching, or analogy. Goatly illustrates this in the following examples:

(4) "Although Atkinson lost that fight...." (1997, p. 106)

(5) "You never know what's around the corner.” (p. 106)

(6) "Too many cooks spoil the broth." (p. 106)

The first two examples (4) and (5) may not effortlessly be understood as metaphors as the phrases "lost that fight" and "around the corner" do not instantly indicate similarity or analogy to a specific vehicle, signaling that his view on metaphor is based on cognition as well. To understand the meaning examples (4) and (5), lexical meanings of lost and around need to be identified, thus signaling differences in the lexical and contextual meaning. Understanding a metaphor based on the similarity, matching, or analogy, as Goatly (1997) states, requires further analysis of how the similarity or analogy can be revealed. Example (6) denotes an analogy of a specific situation, and comprehension can be achieved when the reader can relate the situation of "cooks" and "broth." Cognitively, a cook can make broth, yet when too many cooks are involved in making a particular broth, each cook may have a different ingredient to add that may result in distasteful broth. Such a situation can be applied when too many people in charge lead to an unfavorable outcome.

According to cognitive linguistics, metaphor means apprehending a conceptual domain as another conceptual domain 
(Kövecses, 2010). Metaphor in the cognitive view has two main domains: the source domain, which tends to be concrete, and the target domain assumed to be abstract or less concrete. The conceptual domain of $\mathrm{A}$ as the conceptual domain of $\mathrm{B}$ is the claim of the cognitive view about metaphor. However, it has been noted that there are differences between the conceptual metaphor and metaphorical linguistic expressions (Kövecses, 2010; Lakoff \& Johnson, 1980). For example, the words "indefensible," "attacked every weak point," "demolished," and "won" in examples (1-4) are metaphorical linguistic expressions, while the conceptual metaphor constructed is ARGUMENT IS WAR.

Knowles and Moon come up with the following examples of metaphor:

(7) "The jewel in Northumbria's ecclesiastical crown is Lindisfarne Priory on Holy Island, built as a monastery in 635 and reached by a tidal causeway." (2006, p. 2)

(8) "We used to trash all the teams in Keith Schoolboy League. We had a great squad and no one could touch us." (p. 2)

The words "jewel" and "crown" in example (7) do not refer to their literal meaning as the context leads the reader to Lindisfarne Priory on Holy Island as the "jewel in a crown." Hence, by considering the similarity between "jewel in a crown" and "Lindisfarne Priory on Holy Island," the reader can comprehend the metaphor. Deriving a similar way of thinking, in example (8), the words "trash" and "touch" are used to denote the success of a team in a game, in which "trash" is used to refer to "the opponent side" while "no one could touch" refers to "we" as the winning team.

As illustrated in the examples, the importance of the metaphor in human cognition denotes that metaphors can conceptualize a less concrete experience in terms of a more concrete one. Research by Krisnawati (2014) on metaphors in soccer news discloses a similar notion of understanding one domain as another domain. As our conceptual systems emerge from our bodies, in comprehending a metaphor, the reader needs to identify the source domain, the target domain, as well as a set of mappings between the source and the target domains (Lakoff \& Johnson, 1980). With the power of our cognition, the process of conceptual metaphor comprehension is achieved effortlessly. Lakoff and Johnson (1999) mentioned that all mental operations deal with meaning, and inference deals with unconscious cognitive operations.

Studies on metaphor have uncovered aspects of the character of a text or an author's style in literature (Heywood et al., 2002) and metaphor patterns in a corpus (Crisp et al., 2002). In discourse, writers use metaphors to emphasize the pressure of coherence to create novel metaphors (Kövecses, 2010). Metaphors in EU universities' mission revealed some conceptual metaphors such as COMMERCE, QUANTITY, and COMPETITION metaphors (Arcimaviciene, 2015). In persuading people, metaphors are often used (Charteris-Black, 2004), and it is prevalent in promotional advertisements 
(Bhatia, 2005). Breeze (2013) adds that metaphoricity and analogy make advertisements more powerful. The use of metaphors in tourism discourse has been investigated by Mattiello (2012), stating that there are various metaphorical expressions in the tourism industry and metaphors tend to occur together with hyperboles.

\section{METHOD}

This study employs a qualitative approach that does not pertain to the number of samples and population. According to Creswell and Creswell (2018), the qualitative method is used to explore and comprehend the problem of an individual or group, through which the explanation and interpretation are discussed. This method was selected to describe metaphors about Indonesian nature published in the online travel magazine "Destinasian" Indonesia.

"Destinasian" Indonesia, established in 2013, is the first quarterly travel magazine intended for travelers in Indonesia. In addition to its printed edition, the online version is available at https://destinasian. co.id with theme features of adventure, eat and drink, interview, city scene, photo stories, column, heritage, culture, travel insights, hotel report, and shopping. As the focus of the study was nature, the discourse in the adventure theme was selected. Only discourse describing the nature of Indonesia was collected to disclose the cognition of Indonesian people about their nature manifested in metaphor. Data were collected from the adventure theme of the online "Destinasian" travel magazine from 2016 to 2019. Nineteen articles about Indonesian nature containing metaphors were selected, with eighty-seven metaphorical linguistic expressions identified.

In order to determine linguistic metaphor expressions in tourism discourse, the procedure undertaken was the one developed by Steen et al. (2010) called MIPVU (Metaphor Identification Procedure Vrije Universitet) as employed in the research on metaphor in soccer news by Krisnawati (2014). The procedure describes the steps to decide the basic meaning and the contextual meaning of a word with the assistance of the online Lexico dictionary powered by Oxford. In this study, the procedures were as follows.

1. The authors scrutinized every word in the discourse as a lexical unit, mainly on the verbs and nouns as well as the elements that preceded and followed them. For example, in the expression, the seductive beach, the unit investigated was the beach. As the beach was preceded by seductive, the whole lexical unit to be analyzed was the seductive beach.

2. The authors identified the basic meaning and the contextual meaning of the lexical units under study. The basic meaning is more concrete, specific, and human-oriented (Steen et al., 2010), while the contextual meaning is the meaning of the lexical unit based on the context. An example of this is the expression of trawl international 
tourists by focusing on the basic meaning of trawl. Identifying the basic meaning of trawl to refer to catching fish, the expression of trawl international tourists thus evoked another meaning, namely the contextual meaning.

3. When the basic and contextual meanings were identified, the authors determined the difference in both meanings and checked for the metaphorical linguistic expressions' potential source and target domains. As the focus of the paper was nature, the target domain was nature, and the context of the expressions could reveal the source domain.

\section{RESULTS AND DISCUSSION}

\section{The Theme of Adventure}

The adventure theme of "Destinasian" magazine covers a wide variety of outdoor activities in Indonesian and international tourist destinations. An adventure component tour is recognizable by the activity and location, such as diving, snorkeling, visiting jungles, or looking for unusual wildlife (Buckley, 2006). Mostly promoting the beauty of the places, the writers put enticing titles such as "Want to Have a Cruise Ship Tour? Here is the guideline," "Hunting for Gili," The Most Beautiful Irony in the World," "Expedition of Pinisi with Ayana Komodo," etc. Some texts present outdoor adventures such as 'A Project to Save the Giants of the Sea" and "An Adventure in
Puncak Area." With a focus on Indonesian nature tourism discourse, the description of other countries' nature was excluded.

In tourism discourse, particularly in the adventure theme, tourists communicate their experiences (Djafarova \& Waring, 2012), and geographical and cultural distance is important (Dann, 1996; Heller \& Areni, 2004). Therefore, to create visual images of tourist destinations in the mind of the readers, writers use metaphorical linguistic expressions.

Based on the metaphorical linguistic expressions in the tourism discourse in "Destinasian," as many as eighty-seven expressions about Indonesian nature were collected. The frequency of target domains of tourist destinations, waterfalls, rivers, lakes, seas, waves, beaches, hills, mountains, valleys, and rice fields is depicted in Table 1. In addition, the metaphorical linguistic expressions of the target domains are displayed in Table 2.

\section{Table 1}

Frequency of target domain

\begin{tabular}{lc}
\hline Target Domain & Frequency \\
\hline tourist destination & 21 \\
waterfall & 2 \\
river & 11 \\
lake & 3 \\
sea & 17 \\
waves & 8 \\
beach & 11 \\
hill & 5 \\
mountain & 3 \\
valley & 3 \\
rice field & 3 \\
\hline Total & 87 \\
\hline
\end{tabular}


Table 2

Target domain and metaphorical linguistic expressions

\begin{tabular}{|c|c|}
\hline Target domain & Metaphorical linguistic expression \\
\hline tourist destination & $\begin{array}{l}\text { surga tropis Asia 'Asia's tropical paradise' } \\
\text { menjala turis internasional 'trawl international tourists' } \\
\text { mulai tertangkap radar turis 'starts being caught in radar' } \\
\text { tercium radar turis 'detected by tourists' radar' } \\
\text { Mamasa punya banyak amunisi untuk menjala turis. } \\
\text { 'Mamasa has ammunition to trawl tourists.' }\end{array}$ \\
\hline waterfall & $\begin{array}{l}\text { Air terjun mempertemukan kucuran air tawar dengan air laut } \\
\text { 'The waterfall unites running fresh water and sea water.' }\end{array}$ \\
\hline river & $\begin{array}{l}\text { Sungai mengamuk. } \\
\text { 'The river is raging'. } \\
\text { Sungai mengirimkan banjir. } \\
\text { 'The river sends in flood'. }\end{array}$ \\
\hline lake & $\begin{array}{l}\text { Danau ini tampil dengan wajah tercantiknya. } \\
\text { 'The lake appears in its beautiful face.' }\end{array}$ \\
\hline sea & $\begin{array}{l}\text { laut yang membingkai pulau 'the sea that frames the islands' } \\
\text { rahim laut 'the womb of the sea' }\end{array}$ \\
\hline waves & $\begin{array}{l}\text { tarian ombak 'the dance of the waves' } \\
\text { Ombak mengisap dan menggulung pasir. } \\
\text { 'Waves suck and curl up the sand.' }\end{array}$ \\
\hline beach & $\begin{array}{l}\text { pantai seduktif 'the seductive beach' } \\
\text { pohon-pohon menggerayangi pantai 'trees are fondling the beach' }\end{array}$ \\
\hline hill & perbukitan mengukir lanskap 'the hills engrave the landscape' \\
\hline mountain & $\begin{array}{l}\text { ditaburi gunung-gunung 'sprinkled with mountains' } \\
\text { gunung-gunung jantan yang menusuk langit 'male mountains piercing the sky' } \\
\text { tubuhnya dipenuhi guratan luka sisa letusan. } \\
\text { 'its body is full of wound scratches due to eruptions' } \\
\text { gunung-gunung mengangkangi Bali 'the mountains straddle Bali' }\end{array}$ \\
\hline valley & $\begin{array}{l}\text { lembah hijau yang digerayangi kabut } \\
\text { 'the green valleys fondled by the fog' }\end{array}$ \\
\hline rice field & $\begin{array}{l}\text { sawah memanjakan mata 'rice fields spoil the eyes' } \\
\text { sawah yang mengukir lembah 'rice fields engrave the valleys' } \\
\text { sawah mengukir lereng 'rice fields engrave the slopes' }\end{array}$ \\
\hline
\end{tabular}

A Tourist Destination as Heaven. The conceptualization of nature tourist destinations in Indonesia as heaven is seen in the phrase 'Asia's tropical paradise' signaled by the word paradise. In the dictionary, paradise means "the abode of Adam and Eve before the Fall in the biblical account of the Creation; the Garden of Eden." With such a lexical meaning, paradise used in the expression does not refer to the lexical meaning. Contextually the meaning of paradise is "an ideal or idyllic place or state." Paradise is synonymous with heaven meaning "a place regarded in various religions as the abode of God (or the gods) and the angels, and the good after death, often traditionally depicted as above the sky." Even though nobody has ever been in 
heaven and talked about what heaven looks like, religiously, the situation in heaven can be pictured on people's minds as the definition of heaven exhibits. It supports some research revealing that religion accompanies the mind when seeing nature (Adu-Ampong, 2016; Jaworska, 2017), implying that the nature tourist destinations in Indonesia are of ultimate beauty. Thus, the source domain is heaven.

A Tourist Destination as A Person. As a person, a tourist destination is conceptualized to have human abilities. Dealing with how a tourist destination serves as a place of interest, the tourist destinations are depicted to have the ability to trawl tourists through the expression of "trawl tourists." By demonstrating such an ability, the tourist destinations are conceptualized as fishers doing their jobs to catch fish. The tourists, then, are perceived as fish. In human cognition, catching fish with a net denotes an attempt to obtain as many fish as possible, and such resemblance is viewed in tourist destinations. Concerning nature tourist destinations, the destinations are pictured as fisher people attempting to obtain as many tourists as possible, yielding in the source domain of people. In this expression, the metaphorical expression is used to communicate the intangible tourism features (Buckley, 2006, 2010) such as the atmosphere or friendliness of the local people as well as the tangible features (Djafarova \& Andersen, 2008; Stern, 1998) like the water in the river or the beach surrounded by trees.

\section{A Tourist destination as an Object to be}

Detected. Other expressions perceiving tourist destinations as objects to be detected from the expressions of "caught in radar" and "detected by tourists' radar." The lexical meaning of radar is "a system for detecting the presence, direction, distance, and speed of aircraft, ships, and other objects, by sending out pulses of radio waves which are reflected off the object back to the source." As a military technology, radar is used to detect approaching enemy airplanes or missiles. Civilian airplanes and larger boats and ships use radar as a general aid for navigation (https://www.explainthatstuff. com/radar.html\#uses). The radar detects an approaching object through radio waves. Referring to the use of the radar, expressions "caught in radar" and "detected by tourists' radars" do not bear the lexical meaning. Based on the context, the word radar means tourists detect tourist destinations by technology or other media available to them. The metaphor is in the form of A is B, in which a tourist destination is cognitively perceived as an object. Adding the word radar to the expressions completes the way how tourists know tourist destinations. In these expressions, thus, visual images of the destinations are not pictured, but the way a tourist destination is known to potential tourists is evoked in mind. Finding a tourist destination requires a specific skill and tool, like when radar detects something under close observation. 


\section{Water-related Nature}

Nature as A Person. Water-related nature in the discourse covers waterfalls, rivers, lakes, the sea, and waves. In describing these objects, the writers conceptualize them as persons who can do things such as uniting, getting angry, sending in something, dancing, sucking, and curling up. One disposition of a person demonstrated in the discourse is beauty as expressed in "its beautiful face" when talking about a lake.

The expression "the waterfall is uniting running freshwater and seawater" demonstrates the combination of two different objects. It is written to describe how the waterfall is coming to meet the seawater below it. Another expression, "The river is raging," is used to conceptualize nature as a person that gets angry. Expressing anger is one characteristic of a person, and when a person is angry, one form of anger realization is an aggressive behavior (Verona et al., 2009) and a behavioral outburst (Alia-Klein et al., 2020). The river referred to in the discourse is the holy river, acting aggressively by sending in floods. Despite the misery it has caused, the people living in the area view this as a warning signaling their wrongdoings, as said by one of the prominent leaders. Therefore, the river rage in this sense is not to be misinterpreted as a condition not supporting the promotion of the place as a tourist destination. Conversely, nature has warned them to introspect and think over future actions, exactly which is what this place offers to tourists. Such an expression guides the reader or the tourist on treating nature well as it can get angry.
Unlike expression of the river, the expressions of the lake, sea, and waves are more positive, as seen in tarian ombak, 'the dance of the waves,' and factual condition in laut yang membingkai pulau 'the sea that frames the islands.' These expressions conceptualize nature with the ability to dance and the ability to unite scattered items in one frame as what a person can do. In particular to the ability to unite, it signals that the sea surrounds the islands. Another expression about the sea is rahim laut, 'the womb of the sea.' Only a female has a womb; thus, this expression conceptualizes the sea as a female. The womb in a female person means "the organ in the lower body of a woman or female mammal where offspring are conceived and in which they gestate before birth" and an organ to yield reproductive outcomes (van der Sijpt, 2018). Such meanings contribute to the concept of the sea as a reproducing entity in which many living creatures strive to live and reproduce.

Seeing nature as a person in tourism discourse provides the readers as potential tourists with information on treating nature. Compliments and precautions to nature can help the destinations be preserved and admired and assist them in getting good treatment and positive behaviors from tourists.

\section{Land-based Nature}

Nature as A Person. Beaches, hills, mountains, valleys, and rice fields are land-based nature depicted in the tourism magazine of "Destinasian." As expressed 
in "hills are engraved on the landscape," the picture of how the hills are designed on the landscape will emerge in the reader's mind, signaling that the hills are placed artistically as what a sculptor does. With the word engraving, meaning "cut or carve (a text or design) on the surface of a hard object," a clear and vivid visualization of the landscape is revoked. Sight and touch are the embodiment pictured in the expression.

Different from the hills, the mountains are written in various expressions such as "sprinkled with mountains," "male mountains piercing the sky," "the mountain is full of scratches," and "the mountains straddle." The mountains in all of the expressions are perceived as both living and non-living entities. As a living entity, the mountain can pierce, straddle, and suffer from an injury. The ability of the mountain to do things or experience something is specified in the physical characteristics such as height and sharpness (as the word pierce denotes). In "the mountains straddle," a particular picture comes into mind visualizing how a person's leg is wide apart; thus, it reflects an image metaphor (Lakoff \& Johnson, 1999), in which the mental image of a person straddling is evoked. By relating it to the mountains, the meaning becomes "situated on both sides of a place." In this sense, the attribute of the mountain is its huge size.

Being conceptualized as a person, the mountain can be in a less unfortunate situation as in the expression of "the mountain is full of scratches." Scratches are marks or wounds because of scratching.
Considering the context of the expression, the scratches refer to the marks by eruptions. Eruptions of the mountain are thus pictured as an unfortunate condition due to marks left after an eruption, which is conceptualized as scratches. Evaluating the target domain of the mountain from the expressions, senses of sight, hearing, and touch are evoked. Being conceptualized as a person is also viewed from the expression of "the male mountains piercing the sky." The lexical meaning of male is "of or denoting the sex that produces gametes, especially spermatozoa, with which a female may be fertilized or inseminated to produce offspring." Inferences derived from the metaphorical expression arise from the activation of a collection of meaningful nodes that lead to the activation of other nodes (Lakoff, 2008). Therefore, by relating the physical appearance of a human being to the mountain, a visual image is conceptualized in the mind, and the meaning is comprehended. The word male in the expression refers to the physical characteristics of a male with the ability to pierce.

Attributes of sexual appeal are identified in the words "fondle" and "seductive," as used to picture valleys and beaches expressed in "the fog is fondling the valleys" and "tress are fondling the beach." The lexical meaning of the verb fondle is "stroke or caress lovingly or erotically," while seductive means "tempting, attractive." Viewed from the semantic field, the feature of love and eroticism are covered in the metaphorical expression of the beach and valley. Henceforth, cognitively it denotes 
that both the beach and valleys are pictured as objects that readily accept external treatments due to their sexual attributes. The metaphorical expression in the discourse can draw visual images on tourists' minds (Blasko \& Connine, 1993). For both the word "fondle" and "seductive," the senses evoked are sight and touch.

Being an agricultural country with relatively many rice fields, Indonesia describes rice fields as one tourism attraction as metaphorically expressed in "rice fields spoil the eyes," "rice fields engrave the valleys," and "rice fields engrave the slopes." One of the meanings of spoil is "treat with great or excessive kindness, consideration, or generosity." The phrase "spoil the eyes" entails the great beauty of the rice fields. As the brain is shaped through experiences (Lakoff, 2008), Indonesian people can easily understand how rice fields engrave the valleys and slopes. Through those expressions, awareness of unfamiliar tourism objects can be pictured (Blasko \& Connine, 1993; Dann, 1996). The word "spoil" cognitively evokes the sense of sight, while the word "engrave" is related to sight and touch.

Nature, in general, is conceptualized as a person with a wide range of abilities and attributes. Therefore, when remote nature is pictured in the mind of potential tourists, they will be encouraged to explore it (Cook, 1992). The tourists then become the center of attention due to their capabilities in narrating their experiences (Dann, 2002) and communicating the qualities and attributes of tourism (Stern \& Schroeder, 1994).
Nature as an Entity. In "sprinkle with mountains," the mountain is perceived as a non-living entity. The word sprinkle, meaning "scatter or pour (small drops or particles of a substance) over an object or surface," denotes the mountain as a small drop or particle, or an entity that can be scattered or poured. Relating the expression to the lexical meaning of sprinkle to denote cover surface with small drops or particles, the mountain is not certainly a small drop or particle. Placing mountains as small entities scattered all over the land is understood as comparing the mountains to a larger land on which they reside. Thus, it can be concluded that despite their large size, the mountains are used to signal other existing entities that are incomparably larger. Cognitively, the mental image of "sprinkle with mountains" evokes the picture of mountains that can be spotted in many locations across the country.

\section{CONCLUSION}

Metaphorical linguistic expressions in the Indonesian adventure theme of tourism discourse uncover how language conveys meanings and conceptualizes human cognition about nature. Nature in the Indonesian adventure theme of tourism discourse is conceptualized as heaven, a person, a thing to be detected, and as an entity. The main concept constructed in mind is nature as a person with certain physical qualities and attributes that can guide the reader or the tourist in treating nature. The study also reveals that the target and the source domains of metaphor in tourism discourse are concrete. As the expressions 
evoke the senses of sight, hearing, and touch, they can draw visual images in the mind of the readers as potential tourists, who could be encouraged to explore nature.

This article discusses metaphors in revealing cognition about nature in tourism magazine articles published in a relatively short period. Hence, it is worth including a longer time frame to note the possible differences in human cognition across time frames. Further research may focus on how nature and culture may affect cognition, possibly resulting in more various linguistic metaphorical expressions.

\section{ACKNOWLEDGEMENTS}

The authors wish to thank the Rector of Universitas Padjadjaran, Indonesia, for the Academic Leadership Grant scheme no. 1427/UN6.3.1/LT/2020 for making the research and publication possible.

\section{REFERENCES}

Adu-Ampong, E. A. (2016). A metaphor analysis research agenda for tourism studies. Annals of Tourism Research, 57, 248-250. https://doi. org/10.1016/j.annals.2015.12.013

Alia-Klein, N., Gan, G., Gilam, G., Bezek, J., Bruno, A., Denson, T. F., Hendler, T., Lowe, L., Mariotti, V., Muscatello, M. R., Palumbo, S., Pellegrini, S., Pietrini, P., Rizzo, A., \& Verona, E. (2020). The feeling of anger: From brain networks to linguistic expressions. Neuroscience and Biobehavioral Reviews, 108, 480-497. https:// doi.org/10.1016/j.neubiorev.2019.12.002

Arcimaviciene, L. (2015). EU Universities' mission statements: What is popularized by metaphors. SAGE Open, 5(2). https://doi. org/10.1177/2158244015584378
Bhatia, V. K. (2005). Generic patterns in promotional discourse. In H. Halmari \& T. Virtanen (Eds.), Persuasion across genres: A linguistic approach (pp. 213-225). John Benjamins Publishing Company. https://oi.org/10.1075/ pbns.130.13bha

Bigné, J. E., Sánchez, M. I., \& Sánchez, J. (2001). Tourism image, evaluation variables and after purchase behaviour: Inter-relationship. Tourism Management, 22(6), 607-616. https://doi. org/10.1016/S0261-5177(01)00035-8

Blasko, D. G., \& Connine, C. M. (1993). Effects of familiarity and aptness on metaphor processing. Journal of Experimental Psychology: Learning, Memory, and Cognition, 19(2), 295-308. https:// doi.apa.org/doi/10.1037/0278-7393.19.2.295

Breeze, R. (2013). Corporate discourse. Bloomsbury.

Buckley, R. (2006). Adventure tourism. CAB International Publishing. https://doi. org/10.4324/9781856178358

Buckley, R. (2010). Communications in adventure tour products: Health and safety in rafting and kayaking. Annals of Tourism Research, 37(2), 315-332. https://doi.org/10.1016/j. annals.2009.10.011

Charteris-Black, J. (2004). Corpus approaches to critical metaphor analysis. Palgrave Macmillan UK. https://doi.org/10.1057/9780230000612

Chen, C. F., \& Tsai, D. C. (2007). How do destination image and evaluative factors affect behavioral intentions? Tourism Management, 28(4), 1115-1122. https://doi.org/10.1016/j. tourman.2006.07.007

Cook, G. (1992). The Discourse of advertising. Routledge.

Creswell, J. W., \& Creswell, J. D. (2018). Research and design: Qualitative, quantitative and mixed methods approaches. SAGE Publications Ltd. 
Crisp, P., Heywood, J., \& Steen, G. (2002). Metaphor identification and analysis, classification, and quantification. Language and Literature, 11(1), 55-69. https://doi. org/10.1177/096394700201100105

Cruse, D. A. (2000). Meaning in language. Oxford University Press.

Dann, G. (1996). The language of tourism: A sociolinguistic perspective. CAB International Publishing.

Dann, G. M. S. (2002). The tourist as a metaphor of the social world. In G. Dann (Ed.), The tourist as a metaphor of the social world (pp. 1-18). CAB International Publishing. http://doi. org/10.1079/9780851996066.0001

Djafarova, E., \& Andersen, H. C. (2008). The contribution of figurative devices to representation of tourism images. Journal of Vacation Marketing, 14(4), 291-303. https://doi. org/10.1177/1356766708094751

Djafarova, E., \& Waring, T. (2012). Language of tourism advertising: A pragmatic approach. Tourism Analysis, 17(2), 233-237. https://doi.or g/10.3727/108354212X13388995267986

Elliot, E. A., Cherian, J., \& Casakin, H. (2013). Cultural metaphors: Enhancing consumer pleasure in ethnic servicescapes. Journal of Business Research, 66(8), 1004-1012. https:// doi.org/10.1016/j.jbusres.2011.12.024

Franklin, A. (2003). Tourism: An introduction. SAGE Publications Inc.

Goatly, A. (1997). The language of metaphors. Routledge.

Govers, R., Go, F. M., \& Kumar, K. (2007). Virtual destination image a new measurement approach. Annals of Tourism Research, 34(4), 977-997. https://doi.org/10.1016/j.annals.2007.06.001

Heller, E., \& Areni, C. S. (2004). The effects of conditional indicative language on the comprehension and acceptance of advertising claims. Journal of Marketing Communications, 10(4), 229-240. https://doi. org/10.1080/1352726042000228295

Heywood, J., Semino, E., \& Short, M. (2002). Linguistic metaphor identification in two extracts from novels. Language and Literature: International Journal of Stylistics, 11(1), 35-54. https://doi.org/10.1177/096394700201100104

Jaworska, S. (2017). Metaphors we travel by: A corpus-assisted study of metaphors in promotional tourism discourse. Metaphor and Symbol, 32(3), 161-177. https://doi.org/10.108 0/10926488.2017.1338018

Jaworski, A., \& Pritchard, A. (2005). Discourse, communication and tourism dialogues. In A. Jaworski \& A. Pritchard (Eds.), Discourse, Communication and Tourism (pp. 1-11). Channel View Publications. https://doi. org/10.21832/9781845410216-003

Judd, D. R. (1999). Constructing the tourist bubble. In D. R. Judd \& S. Fainstein (Eds.), The tourist city (pp. 35-53). Yale University Press.

Knowles, M., \& Moon, R. (2006). Introducing metaphor. Routledge.

Krisnawati, E. (2014). Metaphors in Indonesian soccer news. Theory and Practice in Language Studies, 4(1), 24-29. https://doi.org/10.4304/ tpls.4.1.24-29

Kövecses, Z. (2010). Metaphor: A practical introduction (2nd ed.). Oxford University Press.

Laing, J. H., \& Crouch, G. I. (2009). Myth, adventure and fantasy at the frontier: Metaphors and imagery behind an extraordinary travel experience. International Journal of Tourism Research, 11(2), 127-141. https://doi.org/10.1002/jtr.716

Lakoff, G. (2008). The neural theory of metaphor. In R. W. Gibbs Jr. (Ed.), The Cambridge handbook of metaphor and thought (pp. 17-38). Cambridge 
University Press. https://doi.org/10.1017/ CBO9780511816802.003

Lakoff, G., \& Johnson, M. (1980). Metaphors we live by. The University of Chicago Press, Ltd.

Lakoff, G., \& Johnson, M. (1999). Philosophy in the flesh: The embodied mind and its challenge to western thought. Basic Books Perseus Books Group.

Larson, M. (2009). Joint event production in the jungle, the park, and the garden: Metaphors of event networks. Tourism Management, 30(3), 393-399. https://doi.org/10.1016/j. tourman.2008.08.003

Mattiello, E. (2012). Metaphor in tourism discourse: Imagined worlds in English tourist texts on the web. Textus, 25(1), 67-82.

Meethan, K. (2001). Tourism in global society. Palgrave.

Milstein, T. (2016). The performer metaphor: Mother nature never gives us the same show twice. Environmental Communication, 10(2), 227-248. https://doi.org/10.1080/17524032.2015.1018295

Morgan, N., \& Pritchard, A. (2005). On souvenirs and metonymy: Narratives of memory, metaphor and materiality. Tourist Studies, 5(1), 29-53. https:// doi.org/10.1177/1468797605062714

Pink, S. (2007). The future of visual anthropology: Engaging the senses. Routledge.

Scarles, C. (2010). Where words fail, visuals ignite. Opportunities for visual autoethnography in tourism research. Annals of Tourism Research, 37(4), 905-926. https://doi.org/10.1016/j. annals.2010.02.001
Steen, G. J. (2007). Finding metaphor in grammar and usage: A methodological analysis of theory and research. John Benjamins Publishing Company.

Steen, G. J., Dorst, A. G., Berenike Herrmann, J., Kaal, A. A., Krennmayr, T., \& Pasma, T. (2010). A method for linguistic metaphor identification. John Benjamins Publishing Company.

Stern, B. B. (1998). How does an ad mean? Language in services advertising. Journal of Advertising, 17(2), 3-14. https://doi.org/10.1080/00913367. 1988.10673108

Stern, B. B., \& Schroeder, J. E. (1994). Interpretative methodology from art and literary criticism: A humanistic approach to advertising imagery. European Journal of Marketing, 28(8/9), 114-132. https://doi.org/10.1108/03090569410067659

Thrift, N. (2001). Still life in nearly present time: The object of nature. In Bodies of nature ( $\mathrm{pp}$. 34-57). SAGE Publications Inc. https://doi. org/10.4135/9781446221266.n3

Urry, J. (2000). Sociology beyond societies: Mobilities for the 21st century. Routledge.

Urry, J. (2002). The tourist gaze. SAGE Publications Inc.

Urry, J., \& Larsen, J. (2011). The tourist gaze 3.0. SAGE Publications Inc.

van der Sijpt, E. (2018). Wasted wombs: Navigating reproductive interruptions in Cameroon. Vanderbilt University Press. https://doi. org/10.2307/j.ctv16755pr

Verona, E., Sadeh, N., \& Curtin, J. J. (2009). Stressinduced asymmetric frontal brain activity and aggression risk. Journal of Abnormal Psychology, 118(1), 131-145. https://doi. org/10.1037/a0014376 